\title{
THE MULTI-DIMENSIONS OF TEACHERS' ICT LEARNING
}

\author{
Adi Suryani $^{1(*)}$, Soedarso $^{2}$, Niken Prasetyowati ${ }^{3}$, Umi Trisyanti $^{4}$ \\ Institut Teknologi Sepuluh Nopember, Indonesia ${ }^{1234}$ \\ adisuryani.rahman@gmail.com ${ }^{1}$, soedarsoits@gmail.com² ${ }^{2}$, niken@mku.its.ac.id ${ }^{3}$, umi@mku.its.ac.id ${ }^{4}$
}

\begin{abstract}
Received: 30 September 2020 Todays' teachers should respond to their students' learning need in this Revised: 11 Desember 2020 digital era, but frequently they do not know how to operate technology. Accepted: 21 Desember 2020 This situation imposes teachers to survive and grow through self-learning and learning and discovery learning method instead of relying on formal training. This study aims to explore how teachers survive and perform their self-learning. The study adopts a qualitative research method by open ended questions as the instrument of data collection and thematic analysis as the data analysis method. During the study, there are twenty-six senior high school teachers who are collaborated in MGMP Bahasa Inggris Jombang are asked to fill open ended questions which aim to explore their ICT experiences and difficulties. The data show that ICT learning requires the integration of affective, social and cognitive functioning through the process of adaptive learning from authentic environment, individual continuous and group learning. The study shows that teachers are potential adaptive learners, who learn from diverse everyday situations. They are engaging in situated learning process. ICT learning workshops are not the only platforms where they can learn ICT. On daily basis, the teachers learn from other teachers who are more competent, teachers learning communities and their own students
\end{abstract}

Keywords: Self-Ditected Learning; Information and Communication Technology; Continuous Learning; Authentic Environment

(*) Corresponding Author: $\quad$ Suryani, adisuryani.rahman@gmail.com

How to Cite: Suryani, A., Soedarso., Prasetyowati, N., \& Trisyanti, U. (2021). The Multi-dimensions of Teachers' ICT learning. Research and Development Journal of Education, 7 (1), 11-28.

\section{INTRODUCTION}

The rapid development and dispersion of ICT directs teachers to face big challenges. They are not only obliged to deliver materials or information, but also facilitate and show their students how to explore their own materials. This implies that by using ICT, teachers should empower their students to be independent learners by integrating ICT into learning. They should not only introduce and encourage their students to enhance their learning using ICT, but also increase their own professional and self capacities using ICT. Today's teachers should embrace and be ready to live with ICT.

Integrating ICT within their teaching and learning activities give the other challenges. Some teachers may not find any substantial difficulties to learn ICT (Habibu et al., 2012). It is reported that English teachers tend to face competency barriers, insufficient ICT facilities, lack of technical support and less encouragement from authorities (Ghavifekr et al., 2016; Nhu et al., 2019).

This digital era tends to force teachers to adopt technology in their class regardless teachers' readiness to implement it in their classrooms. Some schools may have adequate financial source to conduct ICT tutorials for their teachers. However, some disadvantaged schools may suffer from digital divide/gap, as they do not have sufficient sources to 
facilitate their teachers learning formally. Thus, the teachers need to develop creative individual problem solving by utilizing any resources available at their surroundings.

This implies that the rapid development of ICT encourages teachers to rotate their roles from teachers into students and learn from problems which are emerging from their everyday teaching situations. Thus, this study aims to explore teachers' approaches or ways they develop to survive, do their job and learn ICT. The data are based on teachers' inner-voices or perspectives on learning ICT with natural context. The data are collected through teachers' response on open ended questioners which are distributed to teacher participants during the community service program. The study is concentrated on exploring learning challenges/constraints encountered by teachers in integrating ICT within their routine learning and teaching process and teachers' learning behavior to respond to the ICT challenges.

\section{Teachers and Technology}

Educational changes can only occur when teachers commit to change. ICT can change education/classroom only when it can infiltrate teachers self. This means that teachers' perception and acceptance towards ICT is vital (Vitanova et al., 2015). Similarly, Malinina (2015) supports that the basic component of ICT in education is teachers' knowledge, skill, behavior and motivation towards ICT usage.

When teachers have positive perspective and experience using ICT, it is more likely that they will use it and integrate it with their materials and learning activities in their classrooms. Moreover, teachers' motivation can stimulate them to apply ICT (Copriady, 2015). However, not all teachers are confident to use ICT. Teachers can feel anxious which obstructs the implementation of ICT in classrooms (Rahimi \& Yadollahi, 2011). Raman and Yamat (2014) reveal that teachers' overloading work, hesitancy, ICT experience, age and ICT competencies can significantly impede process of ICT integration. Vitanova et al. (2015) highlight some demographic aspects which affect teachers' ICT competencies: gender, age, work experience, subject and area of schools. ICT integration/implementation barriers can emerge from task and school-related factors. Different from previous studies which emphasize on teachers' factors, Mynř́ková and Novotný (2020) suggest the need to provide social support for teachers' ICT learning, besides encouraging teachers to be more confident and believe on the positive impacts of ICT in their teaching. Furthermore, Baydas and Goktas (2016, p. 172) argue that ICT adoption depends on teachers' willingness to use ICT which is determined by sense of usefulness, ease, social determination, supporting condition and ICT nervousness.

All of these ICT barriers indicate that to be successful ICT learners, teachers should not only able to operate computer, but handle soft and hard sides of technology. There are several elements which should be combined to ensure successful ICT learning: value-motivation which contains teachers' consciousness on the usefulness of ICT, cognition which represents teachers knowledge on how to use technology, operational aspect relates to teachers' capacity to select suitable technology, communicative element which encourage teachers to engage themselves in professional development activities and reflective which enables teachers to assess their efforts/learning (Evtigneev, 2011, cited in Sysoyev \& Evstigneev, 2014, pp. 84-85). Similarly, Røkenes and Krumsuik (2016, pp. 3-4) highlight the importance to equip teachers with integrated ICT-related skills: basic ICT skills, didactic competence, learning strategies and digital building. Several studies propose some approaches to increase teachers' ICT competence. Teachers' ICT skills can be enhanced by building school/institution networking in which teachers can communicate to other people from different contexts (Marcelo et al., 2014). 
Consistent with previous findings, Tedla (2012) highlights the key roles of external and internal aspects in ICT integration.

\section{Teachers as self-directed learners}

Indirectly, the presence of ICT can push teachers to prepare themselves to slowly accept and integrate ICT into their teaching and learning. ICT problems which are encountered by teachers during their everyday teaching and learning may unconsciously encourage teachers to learn ICT on daily basis. They are directed to undertake selfdirected learning. Unconsciously they can engage in self-directed learning. Ramani (2013) highlights the importance of self-directed learning in $21^{\text {st }}$ century. Wagner (2011) reports that teachers' self-directed learning tends to be encouraged by their responsibility and creativity to explore additional knowledge. Self-directed learning strategy potentially exerts positive impacts as self-directed learning is investment towards lifelong learning (Malison \& Thammakoranonta, 2018), tool for promoting lifelong learning (Boyer et al., 2014). Moreover, it can increase learners' motivation, meta-cognition and knowledge (Du, 2013), and lead to academic success (Kan'an \& Osman, 2015).

Self-directed learners tend to develop certain self-characteristics. Enormous scholars have postulated behavioural tendencies of self-directed learners. As mentioned by Edwards (2015), self directed learners are able establish effective communication and shared understanding, self reflection. They are self-reflective, emotionally engaged in learning process, monitor, adapt their learning process and implement relevant strategies (Edwards, 2015). Self-directed learners tend have freedom to decide how, what and when learning process occurs (Ramani, 2013, p. 59), be responsible to their own learning process, monitor and evaluate their own learning (Moradi, 2018). Self directed learners develop certain goals, implement particular strategies and monitor the progress (Tri et al., 2017). Self directed learners are driven by their own needs, conditions and passions (Tri et al., 2017) and develop clearer learning focus and goals compared to more dependent learners (Rydze, 2016).

Enormous studies explore some supporting elements needed to grow self-directed learners. Self-directed learners need certain learning tool (Kim et al., 2014; Suleiman \& Maniam, 2019), supportive learning environment, motivation, relevant learning methods, learning independence, responsibility sense, positive expectation (du Toit-Brits, 2019), learning readiness, strategies, awareness and motivation (Xuan et al., 2018). Similarly, Malison and Thammakoranonta (2018) find that self-directed learning needs strong learning intention, open mindedness, self discipline and self management, and motivation to learn. External support and self-need identification are identified as the basic elements in self-directed learning process (Louws et al., 2017). This self-need identification includes what to learn, how to learn and why they need to learn (Louws et al., 2017). Moreover, Gündüz \& Selvi (2016) suggests several main components, such as learning continuity, learning plan, learning environment management and resources for learning. To be self-directed learners, learners need to have lifelong learning intention, certain behavioural characteristics, such as motivation, self concept, readiness, initiative, autonomy and cognitive skills (Marquez-Leccio, 2016).

Self-directed learning construct highlights the role of self in progressing learning process. Self directed learning is emerging from self-awareness during the process of mastering certain knowledge or skills (van der Walt, 2016, p. 1). They are grown from three aspects: self, purposeful learning and learning process (van der Walt, 2016, p. 3). Giveh et al. (2018, p. 1338) highlight the role of self as different learners may engage differently in self-directed learning process as they have different levels of motivation, efficacy, beliefs, creativity and motivation. Thus, self-directed learning is started from 
learners' self. In spite of the key role of self in self-directed learning, self-directed learners need peer and groups to accelerate learning process (Ramani, 2013). Selfdirected learning process needs external facilitation (Slavit \& McDuffie, 2013).

\section{Teachers' learning and professional development}

To continually develop, teachers need to continually learn. By continual learning, they can boost their students' outcomes and undertake sustainable professional development. Teachers' professional development is defined as structured actions to encourage teachers' changes, teaching improvements for increasing students' outcomes (Darling-Hammond et al., 2017). As key figures in learning (Sagar, 2013), teachers need to improve their teaching quality which impacts on students' learning. Teachers' successful professional development can positively impact on students achievement (Archibald et al., 2011), improve educational quality (Riina, 2019), improve teachers' and students' learning (Yoon, 2016) and assure learning quality (Mizell, 2010). To enhance students' learning skills, teachers need to improve their skills and are ready to impart their knowledge for fostering students' learning (Galaczi et al., 2018).

How teachers can possibly increase their professionalism is researched by enormous educational experts. (artikel a theory) reveals that teachers professionalism can be improved through challenging personal enquiry and collaboration in learning communities (van Benthum et al., 2011). Teachers also can participate in professional development program to develop their professionalism (Darling-Hammond et al., 2017, p. 4). Thus, effective professional development program can be a means for improving teachers' quality.

What makes certain teachers development efforts are more effective than others? Several researchers report that effective teachers' professional development needs to be sustained by various factors. As stated by Darling-Hammond et al (2017, p. 4), effective teachers' professional development programs are focusing on content, involving active learning strategy, using learning models, collaborating, coaching, reflecting or feedbacking, and sustained learning. High-quality professional development program is related to school goals, concentrating on content, applying active learning strategies, collaboration and following up actions (Archibald et al., 2011, p. 3). Effective development program is implementing some cycles of identifying needs, planning learning actions, implementing, reviewing, applying knowledge in practice and reflecting (http://gradutephysioopprtunities.weebly.com/cpd.html., cited in Marfu'ah et al., 2017, p. 297).

Besides focusing on the programs, some researchers highlight the influencing aspects of teachers' self in determining professional development success. As argued by European Union (2009, cited in European Comission, 2013, p. 8), teachers' quality improvement needs teachers' commitment, skills and knowledge. Successful teachers' development program is addressing teachers' and students needs (Reynolds et al., 2016), considering contextual factors, individual variations of each teachers (Petrie \& McGee, 2012), considering students needs, teachers needs, acknowledging tasks and experiences, engaging teachers in actions and considering the action impacts (Timperley et al., 2007). Effective teachers development actions need to be supported by teachers willingness to innovate and adapt (European Comission, 2013), increase their content and pedagogical knowledge (Schieb \& Karabenick, 2011), teachers' changes in attitude, willingness to add more knowledge and improve their skills (Marfu'ah et al., 2017, p. 302), and teachers motivation (Schieb \& Karabenick, 2011).

The social aspect of teachers' learning indicates the needs on external learning support. As mentioned by Bautista and Ortega-Ruiz, (2015), effective teachers 
professional development needs to be supported by building learning infrastructures for fulfilling teachers' and students' needs. It also needs to progress in collaborative environment, address students needs and adjust teaching strategies based on learners' feedback (Hanover Research, 2013).

\section{METHODS}

The primary aim of the study is exploring teachers' ICT learning and understanding meaning behind their effort/action. To reach the aim, the study adopts qualitative research method. Qualitative method is increasingly used for observing human behavior (Mohajan, 2018). The study is extracted from some authors' (author 1, 4 and other community service team) community service program which target senior high school teachers organized in MGMP Bahasa Inggris Jombang. The aim of the community service program is introducing simple and easy applicable technology for the teachersparticipants to enhance their teaching materials. At the end of the program, all of the participants (26 senior high school teachers) are kindly requested to express their ICT difficulties during day by day teaching practices by filling the provided open ended questions. Open ended questions are one of several qualitative techniques that researchers use as method to collect required data (Creswell, 2014). There are four questions are asked to the teachers-participants. Those are: 1) Do you use any forms of ICTs to support your English language teaching? 2) Do you find any barriers/obstacles in using ICT? 3) Have you found any solutions or problem solving to overcome those barriers? 4) What are your ICT visions and missions, especially for supporting your future teaching and learning?

The collected data are analyzed by employing the analytic data strategy. As mentioned by Creswell $(2007$, p. 39), the analytic strategy is collaborating several actions in analyzing data, which include sketching ideas, transcribing, codes identification, relating categories, linking categories to literature concept, creating point of view and presenting the data. Thus, the collected data from the teachers are analyzed through several steps. The first step is reading all of the data across different participants. The second step is developing themes and categories. The third is exploring the data meanings by interpreting and relating to the previous findings or studies. The fourth is presenting the data and analysis. The process of the study is represented in the following figure (Figure 1, The process of the study).

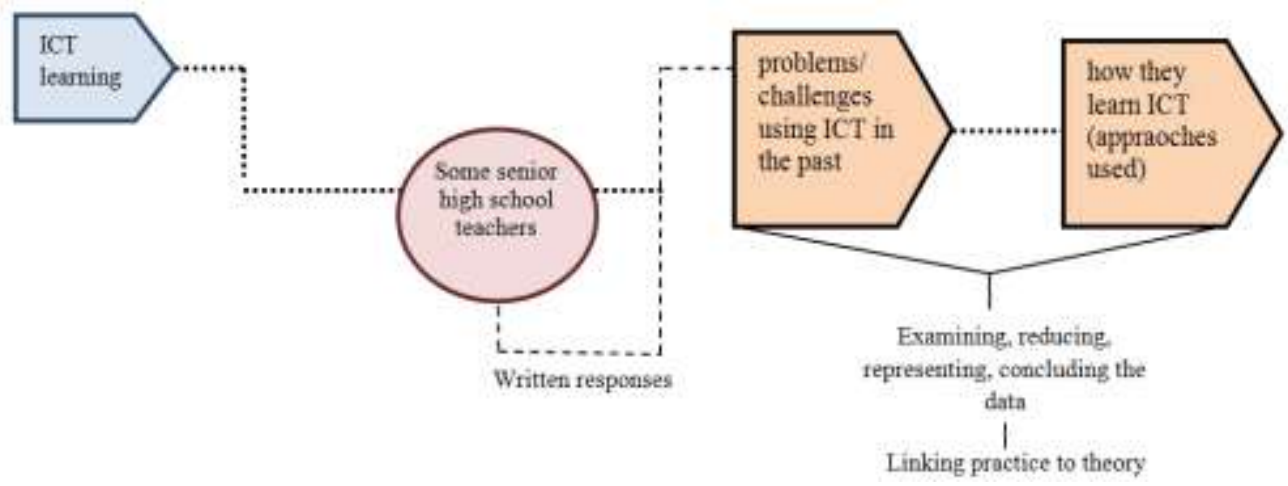

Source: a model which is developed by the authors

Figure 1.

The process of the study 


\section{RESULTS \& DISCUSSION}

The data show two main findings. The first is teachers' self dimension in learning ICT. This first dimension is conceptualized from data meaning extracted from question 1 , 2 , and 3 of the research instruments. In this dimension, teachers are the centre. They are the learning controllers for their own learning efforts. From this aspect, teachers' internal locus of control is significant for their ICT learning success. This means that how they manage their emotion, seek for problem solving initiatives, motivation, resilient capacities determines their learning power. The second aspect is teachers' social dimensions and self-social linkage. The second dimension reflects the interrelationship between teachers' individual self to their social nature. The second dimension is particularly conceptualized from question 2 and 3 of the research instrument.

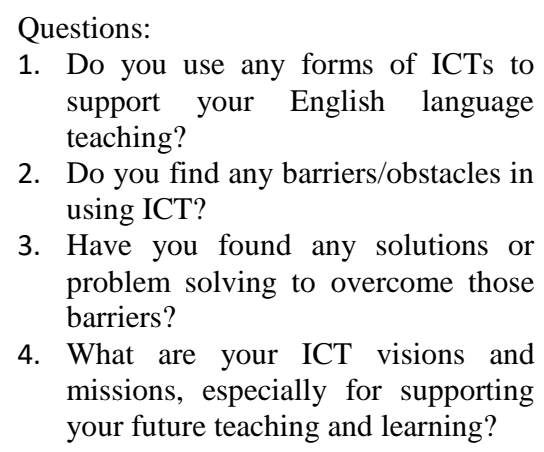

1. Do you use any forms of ICTs to support your English language teaching?

2. Do you find any barriers/obstacles in using ICT?

3. Have you found any solutions or problem solving to overcome those barriers?

4. What are your ICT visions and missions, especially for supporting your future teaching and learning?

Source: a model which is developed by the authors

Figure 2.

Dispersion of the findings

\section{First Aspect: Teachers' Self-Dimension}

The data and the process of extracting meaning form the collected data are classified into three main areas. Those are obstacles of ICT learning, motivation behind ICT learning and how the teachers learn ICT. This section presents what the data say or it is containing some samples of data presentation.

The data show that the teachers take initiative to learn ICT during the process of their teaching and learning. They are learning directly as responses to challenges or problems when they find/encounter some problems with ICT. There are several main problems they encounter. The first obstacles are teachers' individual aspects. These are including teachers' perceived insufficient knowledge, less motivation to learn, and teachers ages). The second obstacle cluster is lack of facility, which includes LCD, electricity and internet connection. The third problem is lack of social encouragement and collaborative culture. The fourth barrier is unsupported learning materials (lack of creativity, students' scores do not increase) and the last barrier is the students digital divide and negative behavior in using technology.

In spite of teaching difficulties which they find in the field, teachers perform experiential learning as responses to cases/challenges they encounter. There are several various reasons why these teachers keep on learning. These are several samples of the collected data:

"Today, technology is getting advanced. It can help us to maximize our way of thinking to achieve optimal result and can compete with others. Do the best for the future and learn more to achieve it." (Teacher-3) 
"IT can make our teaching activity more interesting and the materials that we make can be used for other teaching activity and we can modify our teaching materials as needed." (Teacher-15)

"by using ICT, the students are expected to understand easier, creating students who can master English language, by presenting concrete materials using ICT media." (Teacher-11)

"I use ICT for teaching media to motivate students" (Teacher-16)

The data on some reasons/motivation on learning ICT can be classified into two main categories. The first category is teachers' thinking about their students' life, need and future. This includes teachers' care about their students' learning capacity to live and study in more globalized era in the future, teachers' attention on students' learning motivation, teachers' effort to make their teaching activity is more interesting, effective and efficient, allow students to master English language through ICT, teachers' consideration on easy and cheap access of ICT for students). The second category relates to teachers' aspects. These include teachers' perceived need to increase their competency to assist students in the globalized era, ICT encourages the teachers to actively engange in group learning, their commitment to increase the quality of their teaching, increase their self-professionalism and become motivator for their students.

These motivations encourage teachers to explore what is available in their evironment which they can use to support their learning. They learn from authentic teaching problem and real context/environment. The data show that the teachers use various resources to learn. Below are some data samples of how the teachers learn.

"sometimes I ask some helps from IT staff and sometimes I ask assisstance from students who can handle that technical problem" (Teacher-1)

"I copy the way or adopt approach that my friend from other school use." (Teacher-15)

"I ask help from students who are smart on ICT and IT teachers (Teacher-14)

"to handle ICT difficulty, I usually download programs for self learning and I play again." (Teacher-8)

"I follow ICT trainings for learning media." (Teacher-16)

"I encourage students to be motivated to use ICT and keep on using ICT in school and outside school." (Teacher-9)

The data indicate that the teachers use two strategies to learn ICT. The first is learning from other more competent teachers/their peers. This includes teachers learn from their colleagues who teach at same schools or different schools independently, collaborate in a teamwork or attend the learning opportunities provided by their learning communities. The second approach is by learning from their students. They are not shy to ask their students to help them solve technological issues in their classes. The third is learning from internet by downloading new knowledge online.

The following figure represents the ICT learning obstacles and teachers selfdirected study strategies, which are extracted from the data. The data (as represented in the following figure/Figure 2) show that the teacher-participants experience difficulties rooted from diverse sources, including from their internal self (such as motivation, age 
and knowledge). Since there are no regular trainings from schools, the teachers frequently find situated problem solving by using resources from their surrounding/classroom contexts, such as learning from students, other competent teachers and internet. However, these efforts need teachers' high commitment to learn, intention to improve their competencies and self-professionalism.

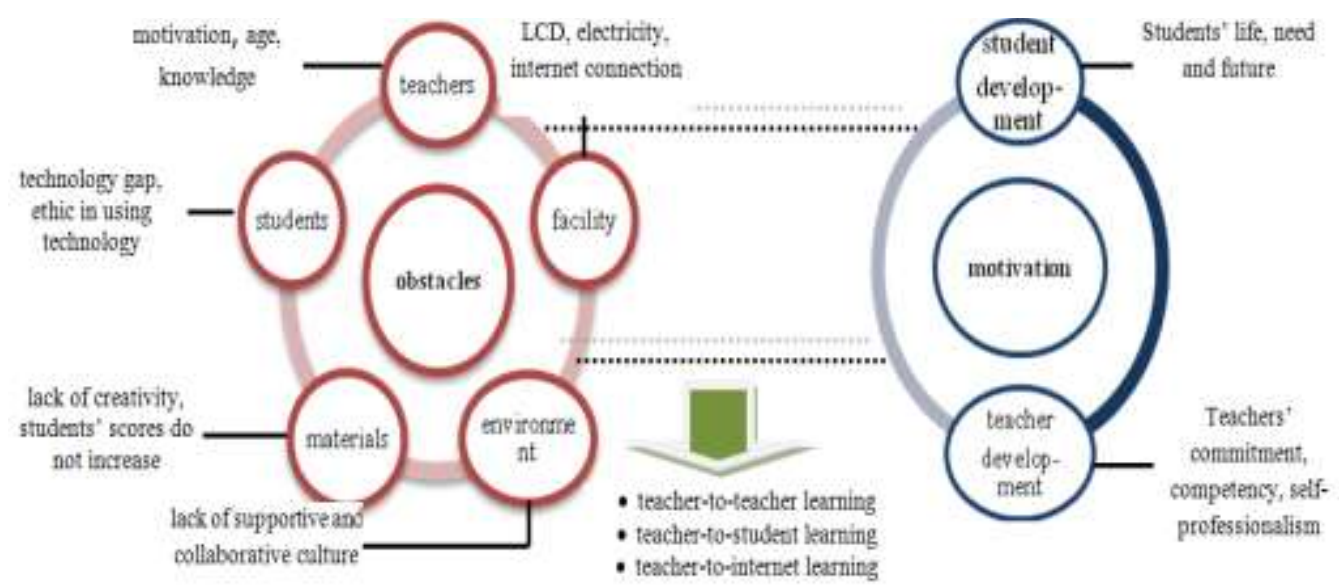

Source: a model which is developed by the authors based on research findings

Figure 3.

ICT learning obstacles and teachers' learning strategies

\section{The Second Aspect: Teachers Social environment and Self-social linkage}

Teachers' ICT learning indicates multi-learning process. The teachers need to engage in authentic and natural learning. Frequently, the teachers perform situated learning in which they learn ICT directly from problems they encountered in classrooms. This type of learning tends to be contextually bounded to their environment.

The study indicates that the teachers-participants are continuously learning needed ICT skills, despite the absence of ICT training or formal ICT education from their schools. They are learning by doing based on their daily needs and teaching practices. Learning by doing is perceived as the most effective learning strategy (Lombardi, 2007). The teachers-participants are consistently learning from their environment by using the available surrounded resources. This indicates that the teachers-participants are engaging in authentic learning process. Authentic learning allows learners to learn from experiences which they get from experimentation of real problems (Lombardi, 2007). The data also show that the teachers-participants perform ICT learning only on what they need, such as operating simple power point for teaching. This indicates that in authentic learning, learners tend to address their real, specific, authentic problems. As noted by (Nikitina, 2011), authentic learning can be triggered by real life experiences, real contexts or situations. Through this approach, learning can be enhanced, as it occurs in real environment, especially when the learnt materials are relevant to learners' need (Corrias et al., 2014). Thus, authentic learning encourages learners to be problem solvers, as they have to critically process required information or materials for learning, and become deep thinkers to solve problems (Neo et al., 2012). Thus, teacher education needs to be based on teachers' real experiences which are connected to teachers' needs and concerns (Korthagen et al, 2001, cited in Korthagen, 2010, p. 104).

The teachers-participants' ICT learning also reveals that they are learning ICT in more real context, rather than through intervention or designed instructional setting. In this situation or context, ICT becomes tool and content for promoting the teachers- 
participants' authentic learning. As mentioned by Lombardi (2007), technology is a tool for facilitating authentic learning. Technology allows learners to use technology in its authentic learning. The teachers-participants' ICT learning also triggers them to learn ICT within its natural context of learning communities. As mentioned by Latham \& Carr (2012), technology learning can encourage learners to engage in authentic learning communities. ICT learning involves connectivism in which learning needs to be flexible and is tied to external world through social networks and technology tools (Mattar, 2018). Besides triggering social engagement, ICT learning deconstructs traditional concept of learning and changes teachers and students roles (Latham \& Carr, 2012). This is as evidenced by how the teachers-participants become learners who are learning from other people, their friends and their students.

The teachers-participants' ICT learning is also relevant to the situated learning construct. This is because the teachers-participants' learning process is embedded in their daily job as teachers who need to constantly up-grade their skills and knowledge. Situated learning construct emerges from a belief that effective learning needs to be embedded in real learning situation where the learners engage in more complex learning process in their real social communities (Norainna, 2018). The situated learning practices rest on social and pragmatic factors in learning and claim that learning is embedded in real situation of actions (Barton et al., 2000). Through situated learning, the teachersparticipants collaborate with others to solve their teaching problems. Situated learning skills enables teachers to use collaboration to solve their problems and lead to decision making, develop teachers confidence by exploring new insights, building community partnership to improve educational skills (Meyers \& Lester, 2013).

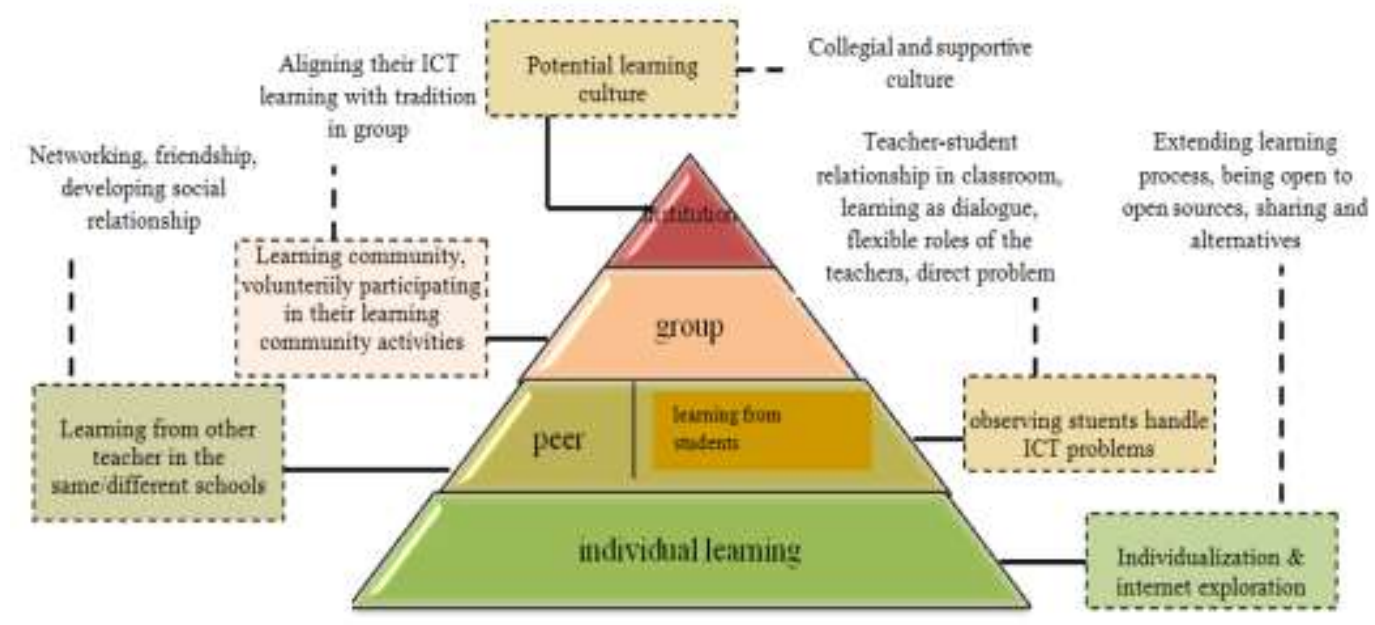

Source: a model which is developed by the authors based on research findings

Figure 4

Teachers' social-based learning

The data also reveal that the teachers-participants' ICT learning is significantly influenced by social environment. Figure 4 shows that the teachers-participants are performing social learning. They are learning from their peers, from their more competent students, engaging in group learning and following their school programs. Many external factors influences the teachers-participants' self as learners, such as group membership, friendship, social relations with students, involvement in volunteering learning activities, and school climate or culture. This indicates that social context also defines the teachersparticipants' learning success. Environment determines learners' growth (Arifin et al., 2018). 
The data show that the teachers-participants join MGMP Bahasa Inggris. They feel that being member of the group makes them more relaxed, enjoy their lives as they can spend not only formal activities, but also informal activities together, such as relaxing and informal gathering for eating together. The teachers-participants' participation in ICT training is also triggered by their MGMP membership and motivation to learn together with their friends from other schools. Group learning or learning in group can increase learners-members' opportunities to share ideas, discuss, being inspired and teach other members (Toki \& Pange, 2013). Thus, group membership can influence the teachersparticipants' learning process. The other influencing factors are the attitudes and motivation demonstrated by teachers' social environment, including their friends or school members (Kovács, 2011), pressures from other teachers or other teachers' behavior (Taylor et al., 2009), the nature of social relationship, social systems (Orey, 2010), learners' social environment background, such as family, parents (Farianti, 2018) and social relations which are shaped by physical environment (Cantero et al., 2016). The teachers-participants' learning is also affected by their institution, peer interaction and school principals' behavior, such as setting goals, trusting and collaboration, supporting active learning (Supovitz et al., 2010). Social actors such as parents, peers, school members and mass media also influence learners' behavior (Arifin et al., 2018). How the teachers-participants' group develop group learning strategy also affects the teachersparticipants' learning process. Thus, it is not only just meeting friends and doing things together, but also developing group strategy for collective learning, such as using nearest neighbor approach which can determine learning effectiveness (Toki \& Pange, 2013).

The data show that the teachers-participants are very pleased when they can meet their friends and learn together. This implies that they have been developing and maintaining their good friendship for long time. To do this, they need appropriate social skills. Thus, learning ICT in social context is not only about learning from other the core content or subject matter of ICT, but also learning and enhancing social skills. This social skill is a tool for establishing group learning, collaborative and cooperative learning. In social learning, learners need to develop positive social interdependence, interaction, proper social skills, team processing (Yusnani, 2018) and inter-agents interaction which involves motivation, attention and perception (Heyes, 2011). This indicates that teachers need to have capacity to engage with others and collaborative capacities, such as trust, empathy and cooperation (OECD, n.d., p. 8). Social factors influencing learners' success are social skills and relationship with others (Magelinskaité-Legkauskienè et al., 2016). Thus, social environment is not exerting one way impact, but two ways or mutual affects. The teachers-participants are not passively shaped by external environment. Instead, the teachers-participants have power to determine their learning success through their social skills. Thus, they are active learners.

The study also finds and acknowledges the multi-social factors which can support the teachers-participants' meaningful ICT learning by linking to other previous studies. The teachers-participants' effective ICT learning requires motivating environment (Daniels, 2011), physical facilities, infrastructure and social facilities (Mege, 2014), interactive learning environment (Ceresia, 2016), motivation from other more competent persons and other more competent users of ICT (Mbalamula, 2016), communities of practice (Snyder \& Wenger, 2010; Wenger, 2010), socialization (Toki \& Pange, 2013), teachers emotional management in social context (Schonert-Reichl, 2017), social collaboration (Fahim \& Haghani, 2012; Raspopovic et al., 2017), teachers' social perspective taking skills (Gehlbach et al., 2012) and cooperative learning skills (Yusnani, 2018). 


\section{Towards the Integration of Teachers' ICT Learning Multi-dimension}

The study affirms the close relationship between the teachers-participants' individual and social learners dimensions. Thus, instead of proposing self-vs-group, it synergizes self and group. This is as represented in Figure 5.

Figure 5 shows that to learn ICT in their daily teaching context, the teachersparticipants are tied to individual and social process. Their learning is influenced by several personal factors, such as motivation, commitment, perception, learning goals and self-awareness as the learning engine. Socially, their learning process is determined by social environment, such as culture, peer, community of practices and situated learning capacity. As mentioned by Quansah (2012), learners' learning activities are influenced by three factors: home, school and individual characteristics. Because learning occurs in both individual and social contexts, the teachers-participants need to develop social and emotional skill. OECD (n.d., p. 9) classifies social-emotional skills into six categories: task performance, emotion regulation, collaboration, open-mindedness, engagement with others and compound skills.

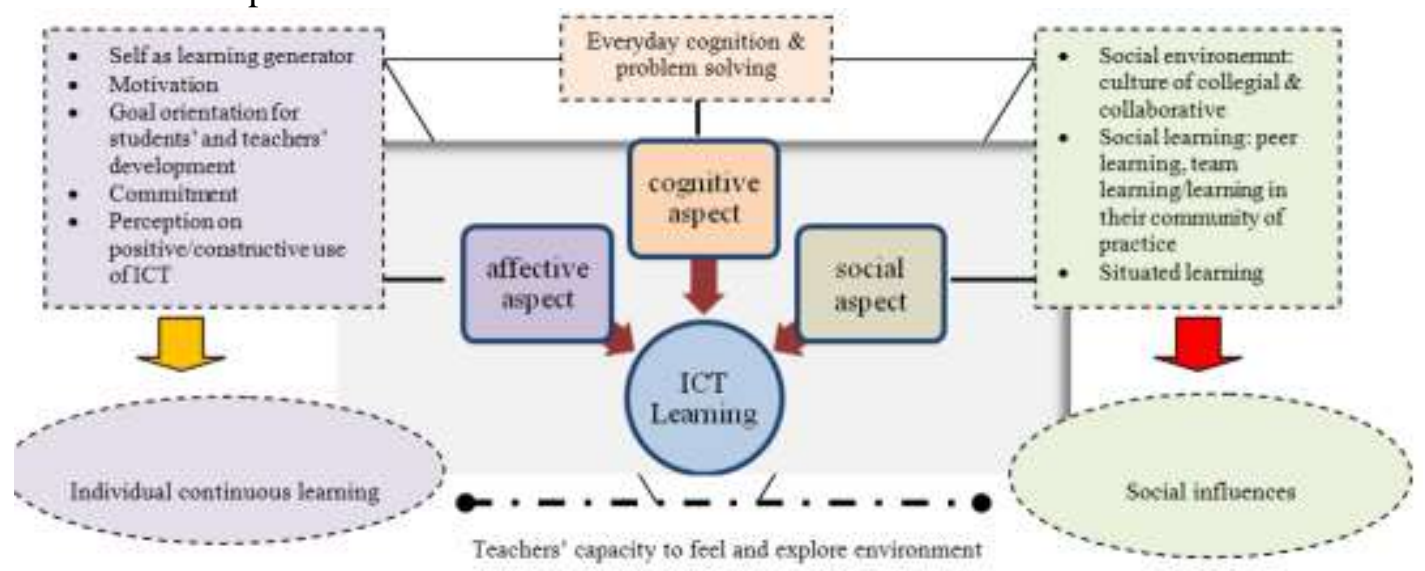

Source: a model which is developed by the authors based on research findings

Figure 5.

Individual and social learning process of the teachers-participants

The study suggests the teachers-participants engage in comprehensive learning approach-social and individual ICT learning strategy. Thus, the study validates other studies which posit relationship between individual and social self. Self is dependent to social as social environment shapes the self-character. As mentioned by Purnama and Rahman (2014), it is expected that the development of individual character is conforming to social guidance in order to reduce inappropriateness of individual behavior and character in social context. Social environment can influence individual through social norm or culture (Walton, 2016). Moreover, individuals tend to have a need to associate with others through, for instance, group membership (Walton, 2016). Furthermore, it is reported that group works can underperform individual efforts (Walton, 2016).

Despite the profound role of social environment on individual learning process, an individual is not a passive self. The teachers-participants, individually tend to feel the learning needs, set different goals, explore solution for their learning problems, explore the alternatives, execute the learning process at different progress from their other friends and sense different levels of learning motivation and other affective features. This indicates that individual self also has power to drive and progress the learning process. The individual self still has power or control in three domains: differential reinforcement, vicarious learning and differential information processing for regulating behavior (Wiliamson, 2017, pp. 7-8). The individual self also has a need to be unique, which 
encourages them to depart from group comfort (Walton, 2016). The individual self also needs to isolate him or herself from group when he or she needs to work with his or her own self to create and come back to group to discuss his or her creative work (Walton, 2016). The individual self's power is also validated by the social cognitive theory which argues that in observational learning process, learners are not simply imitating, but managing their own behaviours (Bandura, 2001, cited in iSALT Team, 2014). This proves the synergy between observational learning in social environment domain and cognition as well as emotion and cognition in individual domain. As revealed by Zakiah and Fajriadi (2020), learners' self regulated learning tends to be affected by their individual factors (such as cognition, self-evaluation and attitude), behavior and social environment. This construct is relevant with Bandura's social cognitive learning theory which views learning as affected by environmental, cognitive and behavioural factors (Bandura, 1991, cited in iSALT Team, 2014). Thus, this study confirms the findings of several previous studies which posit the relationship between individual and social learning construct (DeCaro et al., 2017; Firoozi \& Kazemi, 2017; Handayani et al., 2010; Marriott \& Chebib, 2014; Şenyuva \& Gönül, 2011; Tamura et al., 2015; Wiliamson, 2017; Zakiah \& Fajriadi, 2020). The teachers-participants are not passively created by social environment, but they are exploring their social environment to boost their ICT learning. The teachers-participants also synergize their individual and social selves to enhance their learning.

\section{CONCLUSION}

Teachers' ICT learning is a complex and multidimensional construct. It involves various dimensions of teachers' individual self, social selves and their interrelationship. It is not sufficient for the teachers to only have high motivation and optimism without being supported by facilities and conducive social environment. It needs the integration of teachers self as center and social nature as the center. Thus, the effective teachers' ICT learning needs teachers to be able manage their own self, observe, learn from their social environment and situate self in the social context. They need to be explorative, assertive, feel the challenges and being resilient. The study finds that the teacher-participants explore various ways to learn from their social environment, such as participating in learning community, learning from other more competent teachers, even learning from their millennial students. Teachers' ICT competency can also be potentially increased by improving teachers' capacity to undertake situated learning. They do not have to wait and expect scheduled/formal ICT training from schools. Instead, they can learn progressively from their daily practices and teaching experiences by utilizing their surrounding social resources. Thus, ICT learning needs more than self learning, but also affective, cognitive and social learning process.

\section{REFERENCES}

Archibald, S., Coggshall, J. G., Croft, A., \& Goe, L. (2011). High-Quality Professional Development for All Teachers:Effectively Allocating Resources (Research \& Policy Brief, pp. 1-21). National Comprehensive Center for Teacher Quality.

Arifin, R. binti M., Wahab, N. B. A., Teh, K. S. bin M., \& Otman, Mohd. S. (2018). Influence of Social Environment on Student's Behaviour. International Journal of Academic Research in Business and Social Sciences, 8(7), 930-939. https://doi.org/DOI: 10.6007/IJARBSS/v8-i7/4520 
Barton, K., McKellar, P., \& Maharg, P. (2000). Situated Learning and the Management of Learning: A Case Study. The Law Teacher, 34(2), 141-163. https://doi.org/DOI: 10.1080/03069400.2000.9993052

Bautista, A., \& Ortega-Ruiz, R. (2015). Teacher Professional Development: International Perspectives and Approaches. Psychology, Society, \& Education, 7(3), 240-251.

Baydas, O., \& Goktas, Y. (2016). Influential factors on preservice teachers' intentions to use ICT in future lessons. Computers in Human Behavior, 56, 170-178. http://dx.doi.org/10.1016/j.chb.2015.11.030

Boyer, S. L., Edmondson, D. R., Artis, A. B., \& Fleming, D. (2014). Self-Directed Learning: A Tool for Lifelong Learning. Journal of Marketing Education, 36(1), 20-32. https://doi.org/DOI: 10.1177/0273475313494010

Cantero, J. M. M., Mira, R. G., \& López-Chao, V. (2016). Influence of Physical Learning Environment in Student's Behavior and Social Relations. Anthropologist, 25(3), 249-253.

Ceresia, F. (2016). Interactive learning environments (ILEs) as effective tools for teaching social sciences. Procedia - Social and Behavioral Sciences, 217, 512 521. https://doi.org/doi: 10.1016/j.sbspro.2016.02.031

Copriady, J. (2015). Self- motivation as a mediator for teachers' readiness in applying ICT in teaching and learning. Procedia - Social and Behavioral Sciences, 176, 699 - 708. https://doi.org/doi: 10.1016/j.sbspro.2015.01.529

Corrias, A., Buist, M. L., \& Soong, S. K. A. (2014). Designing a technology-enhanced authentic learning environment for a large engineering class. Rhetoric and Reality. Critical Perspective on Educational Technology.

Creswell, J. W. (2007). Qualitative inquiry ad research design. Choosing among five approaches (2nd ed.). SAGE Publications Inc.

Creswell, J. W. (2014). Research design: Qualitative, quantitative, and mixed methods approaches (4th ed.). SAGE Publications, Inc.

Daniels, E. (2011). Creating motivating learning environments: Teachers matter. Teachers can influence students' motivation to achieve in school. Middle School Journal, 43(2), 32-37.

Darling-Hammond, L., Hyler, M. E., \& Gardner, M. (2017). Effective Teacher Professional Development (pp. 1-64). Learning Policy Institute. https://learningpolicyinstitute.org/product/teacher-prof-dev

DeCaro, D. A., Arnold, C. A., Boamah, E. F., \& Garmestani, A. S. (2017). Understanding and applying principles of social cognition and decision making in adaptive environmental governance. Ecology and Society, 22(1). https://doi.org/10.5751/ ES-09154-220133

Du, F. (2013). Student Perspectives of Self-Directed Language Learning: Implications for Teaching and Research. International Journal for the Scholarship of Teaching and Learning, 7(2), 1-16.

du Toit-Brits, C. (2019). A focus on self-directed learning: The role that educators' expectations play in the enhancement of students' self-directedness. South African Journal of Education, 39(2), 1-11. https://doi.org/10.15700/saje.v39n2a1645

Edwards, N. (2015). An Analysis of the Characteristics of Self-Directed Learners and Strategies to Enhance Self-Directed Learning in Education Systems: Transcending Boundaries. The Asian Conference on Education 2015. www.iafor.org

European Comission. (2013). Supporting teacher competence development for better learning outcomes (Education and Training). European Comission. http://ec.europa.eu/education/school-education/teacher-cluster_en.htm 
Fahim, M., \& Haghani, M. (2012). Sociocultural Perspectives on Foreign Language Learning. Journal of Language Teaching and Research, 3(4), 693-699. https://doi.org/doi:10.4304/j1tr.3.4.693-699

Farianti, S. (2018). The Influence of Social Factors on Students' Achievement in Learning English. Journal of Linguistics, Literature \& Language Teaching, IV(2), 53-75.

Firoozi, M. R., \& Kazemi, A. (2017). The Role of Socio-Cognitive Variables in Predicting Learning Satisfaction in Smart Schools. International Electronic Journal of Elementary Education, 9(3), 613-626.

Galaczi, E., Nye, A., Poulter, M., \& Allen, H. (2018). Teacher Professional Development (Cambridge Assessment English Perspectives, pp. 4-35). Cambridge Assessment-English.

Gehlbach, H., Young, L. V., \& Roan, L. K. (2012). Teaching social perspective taking: How educators might learn from the Army. Educational Psychology, 1-15.

Ghavifekr, S., Kunjappan, T., Ramasamy, L., \& Anthony, A. (2016). Teaching and Learning with ICT Tools: Issues and Challenges from Teachers' Perceptions. Malaysian Online Journal of Educational Technology, 4(2), 38-57.

Giveh, F., Ghobadi, M., \& Zamani, Z. (2018). Self-directed Learning in L2 Acquisition: A Review of Theory, Practice, and Research. Journal of Language Teaching and Research, 9(6), 1335-1343. http://dx.doi.org/10.17507/jltr.0906.24

Gündüz, G. F., \& Selvi, K. (2016). Developing a "Self-directed Learning Preparation Skills Scale for Primary School Students": Validity and Reliability Analyses. Universal Journal of Educational Research, 4(10), 2317-2334. https://doi.org/DOI: 10.13189/ujer.2016.041011

Habibu, T., Al-Mamun, Md. A., \& Clement, C. (2012). Difficulties Faced by Teachers in Using ICT in Teaching-Learning at Technical and Higher Educational Institutions of Uganda. International Journal of Engineering Research \& Technology, 1(7), ISSN: 2278-0181.

Handayani, L., Kosnin, A. M., \& Jiar, Y. K. (2010). The Role of Social Support, Knowledge, Attitude, and Self-Efficacy in Breastfeeding: Social Cognitive Perspective. Buletin Psikologi, 18(1), 13 - 18.

Hanover Research. (2013). Professional Development for Personalized Learning Practices (pp. 3-26). Hanover Research.

Heyes, C. (2011). What's Social About Social Learning? Journal of Comparative Psychology, 1-10. https://doi.org/doi: 10.1037/a0025180

iSALT Team. (2014). Social Cognitive Theory (Paper 4; ISAL T Resources: Theories, Concepts, and Measures). Minnesota State University. http://cornerstone.lib.mnsu.edu/isalt_resources/4

Kan'an, A., \& Osman, K. (2015). The Relationship between Self-Directed Learning Skills and Science Achievement among Qatari Students. Creative Education, 6, 790-797.

Kim, M., Jung, E., Altuwaijri, A., Wang, Y., \& Bonk, C. (2014). Analyzing the Human Learning and Development Potential of Websites Available for Informal Learning. International Journal of Self-Directed Learning, 11(1), 12-28.

Korthagen, F. A. J. (2010). Situated learning theory and the pedagogy of teacher education: Towards an integrative view of teacher behavior and teacher learning. Teaching and Teacher Education, 26, 98-106. https://doi.org/doi:10.1016/j.tate.2009.05.001 
Kovács, Á. (2011). The Role of Social Environment in the Formation of Adult English Language Learners' Attitudes to Learning English: A Pilot Study. WoPaLP, 5, $100-117$.

Latham, G., \& Carr, N. (2012). Authentic Learning for Pre-service Teachers in a Technology-Rich Environment. Journal of Learning Design, 5(1), 32-42.

Lombardi, M. M. (2007). Authentic Learning for the 21st Century: An Overview (ELI Paper 1, pp. 1-12). Educause Learning Initiative.

Louws, M. L., Meirink, J. A., van Veen, K., \& van Driel, J. H. (2017). Teachers' selfdirected learning and teaching experience: What, how, and why teachers want to learn. Teaching and Teacher Education, 66, 171-183. http://dx.doi.org/10.1016/j.tate.2017.04.004

Magelinskaitė-Legkauskienè, Š., Legkauskas, V., \& Kepalaitè, A. (2016). Relative Importance of Social Factors Linked to Academic Achievement in the 1st Grade. Social Welfare Interdisciplinary Approach, 2(6), 30-41. https://doi.org/DOI: $10.21277 /$ sw.v2i6.265

Malinina, I. (2015). ICT Competencies of Foreign Languages Teachers. Procedia - Social and Behavioral Sciences, 182, 75-80. https://doi.org/doi: 10.1016/j.sbspro.2015.04.740

Malison, K., \& Thammakoranonta, N. (2018). An Exploratory Study of Self-Directed Learning: The Differences between it and Non-it Employees in Thailand. Journal of Entrepreneurship Education, 21(3), 1-16.

Marcelo, C., Pérez, L., \& Quintana, M. (2014). School networks to promote ICT competences among teachers. Case study in intercultural schools. Computers in Human Behavior. Computers in Human Behavior, 30, 442-451. https://doi.org/10.1016/j.chb.2013.06.024

Marfu'ah, S., Djatmiko, I. W., \& Khairudin, Moh. (2017). Learning Goals Achievement of a Teacher in Professional Development. Jurnal Pendidikan Teknologi Dan Kejuruan UNY (JPTK), 295-303. https://doi.org/10.21831/jptk.v23i3.13871

Marquez-Leccio, B. J. (2016). Self-Directed Learning: Teacher and Learner. International Education \& Research Journal, 2(5), 108-109.

Marriott, C., \& Chebib, J. (2014). The Effect of Social Learning on Individual Learning and Evolution. Psychology, Computer Science, Biology. https://doi.org/DOI:10.7551/978-0-262-32621-6-CH118

Mattar, J. (2018). Constructivism and connectivism in education technology: Active, situated, authentic, experiential, and anchored learning. Revista Iberoamericana de $\begin{array}{llll}\text { Educación } \quad a \quad \text { Distancia, } & \text { 21(2). https://doi.org/DOI: }\end{array}$ https://doi.org/http://dx.doi.org/10.5944/ried.21.2.20055

Mbalamula, Y. S. (2016). Role of ICT in Teaching and Learning: Influence of Lecturers on Undergraduates in Tanzania. Advances in Research, 8(3), 1-11. https://doi.org/DOI: 10.9734/AIR/2016/30283

Mege, C. A. (2014). Influence of School Environmental Factors on Teaching-Learning Process in Public Primary Schools in Lower Nyokal Division, Homa-Bay District, Kenya [Thesis]. University of Nairobi.

Meyers, S., \& Lester, D. (2013). The Effects of Situated Learning Through a Community Partnership in a Teacher Preparation Program. SAGE Open, 1-9. https://doi.org/DOI: 10.1177/2158244013497025

Mizell, H. (2010). Why professional development matters (Edited by V. von Frank). Learning Forward.

Mohajan, H. K. (2018). Qualitative Research Methodology in Social Sciences and Related Subjects. Journal of Economic Development, Environment and People, 7(1), 23-48. 
Moradi, H. (2018). Self-directed Learning in Language Teaching-learning Processes. Modern Journal of Language Teaching Methods, 8(6), 59-64.

Mynř́ková, L., \& Novotný, L. (2020). Knowledge Society Failure? Barriers in the Use of ICTs and Further Teacher Education in the Czech Republic. Sustainability, 12(6933), 1-19. https://doi.org/doi:10.3390/su12176933

Neo, M., Neo, K. T.-K., \& Tan, H. Y.-J. (2012). Applying Authentic Learning Strategies in a Multimedia and Web Learning Environment (MWLE): Malaysian Students' Perspective. TOJET: The Turkish Online Journal of Educational Technology, 11(3), 50-60.

Nhu, P. T. T., Keong, T. C., \& Wah, L. K. (2019). Issues and Challenges in Using ICT for Teaching English in Vietnam. CALL-EJ, 20(3), 140-155.

Nikitina, L. (2011). Creating an Authentic Learning Environment in the Foreign Language Classroom. International Journal of Instruction, 14(1), 33-46.

Norainna, P. H. S. (2018). Situated Learning Theory: The Key to Effective Classroom Teaching? HONAI: International Journal for Educational, Social, Political \& Cultural Studies, 1(1). www.journals.mindamas.com/index.php/honai

OECD. (n.d.). Social and Emotional Skills Well-being, connectedness and success. OECD.

Orey, M. (2010). Emerging Perspectives on Learning, Teaching, and Technology (Edited by M. Orey). the Jacobs Foundation.

Petrie, K., \& McGee, C. (2012). Teacher Professional Development: Who is the learner? Australian Journal of Teacher Education, 37(2), 59-72.

Purnama, D. S., \& Rahman, A. M. (2014). Character education and personal social guidance counseling and its effects on personal social competences. Journal of Education and Practice, 7(1), 72-83.

Quansah, R. (2012). Social Context \& its Influence on Performance in Social Context \& its Influence on Performance in School [Thesis]. City College of New York.

Rahimi, M., \& Yadollahi, S. (2011). Computer anxiety and ICT integration in English classes among Iranian EFL teachers. Procedia Computer Science, 3, 203-209. https://doi.org/doi:10.1016/j.procs.2010.12.034

Raman, K., \& Yamat, H. (2014). Barriers Teachers Face in Integrating ICT During English Lessons: A Case Study. The Malaysian Online Journal of Educational Technology, 2(3), 11-19.

Ramani, B. V. (2013). Self Directed Learning and Other Learning Strategies to Learn English Language. IOSR Journal Of Humanities And Social Science, 13(5), 58-60.

Raspopovic, M., Cvetanovic, S., Medan, I., \& Ljubojevic, D. (2017). The Effects of Integrating Social Learning Environment with Online Learning. International Review of Research in Open and Distributed Learning, 18(1).

Reynolds, R., Notari, M., \& Tavares, N. J. (2016). Teachers' professional development. In 21 st Century Skills Development through Inquiry Based Learning From Theory to Practice. (Edited by Chu, S., Reynolds, R., Notari, M., Taveres, N., Lee, C.). Springer Science.

Riina, V. (2019). Innovating Professional Development in Compulsory Education. An analysis of practices aimed at improving teaching and learning (EUR $29622 \mathrm{EN}$; A Science for Policy Report, pp. 1-69). Joint Research Centre (JRC). doi:10.2760/948518

Røkenes, F. M., \& Krumsvik, R. (2016). Prepared to teach ESL with ICT? A study of digital competence in Norwegian teacher education. Computers \& Education, 97, 1-20. https://doi.org/10.1016/j.compedu.2016.02.014.

Rydze, OxanaA. (2016). Characteristics of ten-year old self-directed learners. SHS Web of Conferences. EEIA 2016. https://doi.org/DOI: 10.1051/shsconf/20162901060 
Sagar, H. (2013). Teacher Change in Relation to Professional Development in Entrepreneurial Learning [Dissertation]. University of Gothenburg.

Schieb, L. J., \& Karabenick, S. A. (2011). Teacher Motivation and Professional Development: A Guide to Resource (Math and Science Partnership - Motivation Assessment Program, pp. 6-36). University of Michigan.

Schonert-Reichl, K. A. (2017). Social and Emotional Learning and Teachers. The Future of Children, 27(1), 137-155. https://doi.org/DOI: 10.1353/foc.2017.0007

Şenyuva, Z., \& Gönül, Ö. Ö. (2011). The Impact of Social Learning on Constructing Person - Organization Fit. International Journal of Business and Social Science, 2(11), 154-158.

Slavit, D., \& McDuffie, A. R. (2013). Self-Directed Teacher Learning in Collaborative Contexts. School Science and Mathematics, 113(2), 94-105.

Snyder, W. M., \& Wenger, E. (2010). Our World as a Learning System: A Communitiesof-Practice Approach. In Social Learning Systems and Communities of Practice (C. Blackmore (ed.), pp. 107-124). The Open University.

Suleiman, M. A. M., \& Maniam, M. (2019). A Case Study of Self-Directed Learning Using Movie to Promote Oral Communication. Journal of English Teaching Applied Linguistics and Literatures, 2(1), 16-27. https://doi.org/DOI: 10.20527/jetall.v2i1.7372

Supovitz, J., Sirinides, P., \& May, H. (2010). How Principals and Peers Influence Teaching and Learning. Educational Administration Quarterly, 46(1), 31-56. https://doi.org/DOI: 10.1177/1094670509353043

Sysoyev, P. V., \& Evstigneev, M. N. (2014). Foreign Language Teachers' Competency and Competence in Using Information and Communication Technologies. Procedia - Social and Behavioral Sciences, 154, 82-86. https://doi.org/doi: 10.1016/j.sbspro.2014.10.116

Tamura, K., Kobayashi, Y., \& Ihara, Y. (2015). Evolution of individual versus social learning on social networks. J. R. Soc. Interface, 12(20141285), 1-9.

Taylor, I. M., Ntoumanis, N., \& Smith, B. (2009). The Social Context as a Determinant of Teacher Motivational Strategies in Physical Education. Psychology of Sport and Exercise, 10(2), 235-243.

Tedla, B. A. (2012). Understanding the Importance, Impacts and Barriers of ICT on Teaching and Learning in East African Countries. International Journal for ELearning Security, 2(2), 199-207.

Timperley, H., Wilson, A., Barrar, H., \& Fung, I. (2007). Teacher Professional Learning and Development Best Evidence Synthesis Iteration [BES] (pp. 1-220). the Ministry of Education.

Toki, E. I., \& Pange, J. (2013). Social Learning Theories as tools for learning in an ICT educational system. The Online Journal of New Horizons in Education, 3(1), 5355.

Tri, T. M., van Hong, B., \& Xuan, V. T. (2017). Self-directed learning in the context of internationalization in TVET in Vietnam. Tvet-Online.Asia, 9, 1-14.

van Benthum, N., Gulikers, J., de Jong, F., \& Mulder, M. (2011). A theory of improvement for teacher professional development in assessment for learning. 111.

van der Walt, H. (2016). The feasibility of grafting self-directed learning theory onto the capability theory. In Self-directed learning research. An imperative for transforming the educational landscape (Edited by E. Mentz\&I. Oosthuizen, pp. 1-34). AOSIS (Pty) Ltd. DOI: http://www.dx.doi.org/10.4102/aosis.sdlr.2016.03

Vitanova, V., Atanasova-Pachemska, T., Iliev, D., \& Pachemska, S. (2015). Factors Affecting the Development of ICT Competencies of Teachers in Primary Schools. 
Procedia - Social and Behavioral Sciences, 191, 1087 - 1094. https://doi.org/doi: 10.1016/j.sbspro.2015.04.344

Wagner, S. R. (2011). After the Final Bell: The Self-Directed Learning Practices of Elementary Teachers [Dissertation]. University of Tennessee.

Walton, A. P. (2016). Creativity and a human dichotomy: Individual or part of a team? In Multidisciplinary Contributions to the Science of Creative Thinking (pp. 85-102).

Wenger, E. (2010). Communities of Practice and Social Learning Systems: The Career of a Concept. In Social Learning Systems and Communities of Practice (C. Blackmore (ed.), pp. 179-197). The Open University.

Wiliamson, P. A. (2017). Individual Difference Variables and Social Learning: An Investigation into Expectancies [University of South Carolina]. https://scholarcommons.sc.edu/aiken_psychology_theses/32

Xuan, L. Y., Razali, A. B., \& Samad, A. A. (2018). Self-Directed Learning Readiness (SDLR) Among Foundation Students from High and Low Proficiency Levels to Learn English Language. Malaysian Journal of Learning and Instruction, 15(2), 55-81.

Yoon, K. (2016). Professional Development and its Impact on Teacher and Pupil Learning: A Community of Practice Case Study in South Korea [Dissertation]. The University of Birmingham.

Yusnani. (2018). Theoretical Perspectives on Cooperative Learning. KnE Social Sciences, 976-986. https://doi.org/DOI 10.18502/kss.v3i4.2005

Zakiah, N. E., \& Fajriadi, D. (2020). Self regulated learning for social cognitive perspective in mathematics lessons. Journal of Physics: Conference Series, 1613(012049), 1-6. https://doi.org/doi:10.1088/1742-6596/1613/1/012049 